\title{
Home-Based Enterprises in the International Kampong of Sosrowijayan: Housing Typology and Hybrid Cultural Approach to Tourism Development
}

\author{
Suparwoko \\ Lecturer, Department of Architecture, \\ Islamic University of Indonesia, \\ Yogyakarta, Indonesia \\ suparwoko@uii.ac.id
}

\author{
Wiryono Raharjo \\ Lecturer, Department of Architecture, \\ Islamic University of Indonesia, \\ Yogyakarta, Indonesia \\ raharjo@uii.ac.id
}

\begin{abstract}
This paper analyses home-based enterprises focusing on housing space typology and the hybrid cultural approach to the restaurant interior-exterior arrangement in the International Kampong of Sosrowijayan, Yogyakarta. Homebased enterprise (HBE) is defined as a home that functions as both a residence and a income generator. It is achieved through economic activities within the residential spaces, i.e., the space inside and outside the house, with unlimited type of work, carried out by non-family or family members as employees, yet they have bounded by no definite rules. The Eastern Sosrowijayan Kampong, which is better known as Kampung Internasional (International Kampong), is an informal residential area located on the western part of Malioboro street, and south of the Main Railway Station of Yogyakarta (Tugu Station). The case study method conducted in making this paper is qualitative by describing the housing space typology concerning on the home-based enterprises and spaces arrangement based on different services to the visitors in Sosrowijayan Kampong. The research found that housing space typologies are based on various enterprises in the case study including accommodation, travel agencies, tourist guides, businesses related to hotel services and facilities such as laundry, restaurants, souvenir shops and tourist information. Another finding was that the restaurant business in Sosrowijayan as the International Kampong is able to represent a unique hybrid culture that creates a different performance of interior and exterior arrangement. This could occur because of a mixture style of services between local and western cultures as they cater both international and domestic visitors or tourists in many seasons.
\end{abstract}

Keywords: HBE, housing typology, hybrid culture, international Kampong, Yogyakarta

\section{INTRODUCTION}

\subsection{Tourist Visits in Yogyakarta}

Yogyakarta is one of the provinces in Indonesia that is always developing. This development occurs both from the economic, social, cultural sectors to the urban spatial layout. During the 2013-2017 period, the development of DIY tourists had always been increased, both foreign and domestic tourists. In 2017 there were 4.8 million domestic tourists visited Yogyakarta, this number has been exceeded the target of 4.5 million domestic tourists. Meanwhile, for foreign tourists, there were 397,951 recorded in 2017, it also passed the target of 387,000 [1][2].
The high number of tourists in the city of Yogyakarta is caused by several things. The emergence of new tourism attractions in Yogyakarta is considered to contribute in boosting tourist arrivals [3]. In addition, the image of Yogyakarta, known as a city of culture also plays an important role in bringing tourists. This is certainly reinforced by the establishment of Yogyakarta as an ASEAN cultural city (2018-2019). This predicate was given by the ASEAN Ministers Responsible for Culture and Arts (AMCA and Asean Senior Officials Responsible on Culture and Arts (SOMCA) Meeting held in the city of Yogyakarta in 2018 [4][5][6]. According to Director General of culture Kemendikbud, Hilmar Farid, Yogyakarta is worthy of the title as a cultural capital of ASEAN due to has a royal history that is still preserved until to now.

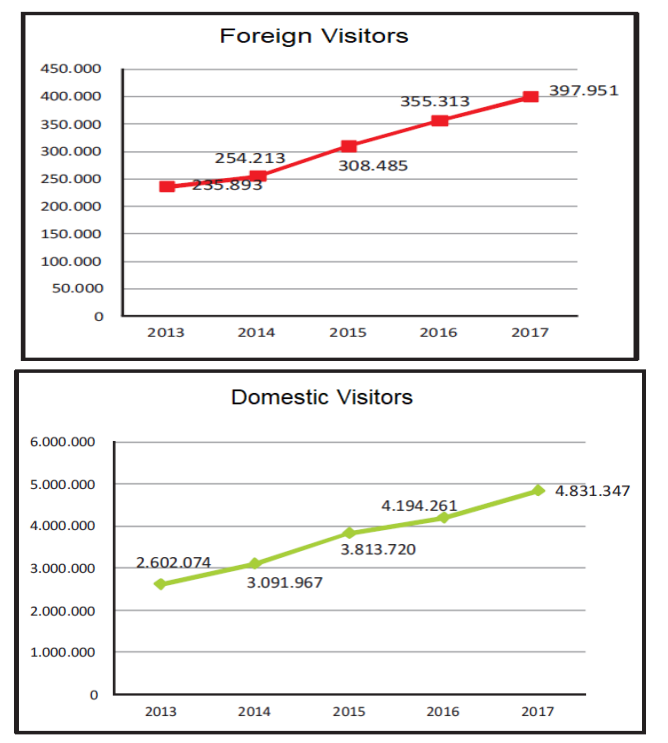

Fig 1. Chart of Tourist Development to DIY in 2013-2017 [1]

All the livelihood of the Java community as guidance unwavering look of everyday life that looked at the activities of customs and traditions, language, social, and arts. [1],[5],[7]. In addition, many annual cultural festivals are held in Yogyakarta such as Artjog, Ngayogjazz festival, Jogja International Heritage Walk, Malioboro Street Performance, Yogyakarta Art Festival (FKY) and others can encourage the existence of Yogyakarta as a cultural city [2]. 
The Tourism Sector has been succeeded in boosting Regional Original Revenue. Increasing the number of tourists to DIY is a challenge for Yogyakarta. These challenges require appropriate and contextual handling in accordance with the situation that occurs in Yogyakarta.

\subsection{Sosrowijayan as an International Kampong}

Sosrowijayan Kampong is known as an international Kampong, located in Pasar Kembang area, right in the alley II Sosrowijayan Wetan, Sosromenduran Kampong. The area is located between Jalan Pasar Kembang and Jalan Sosrowijayan with an area of about 1.39 hectares.

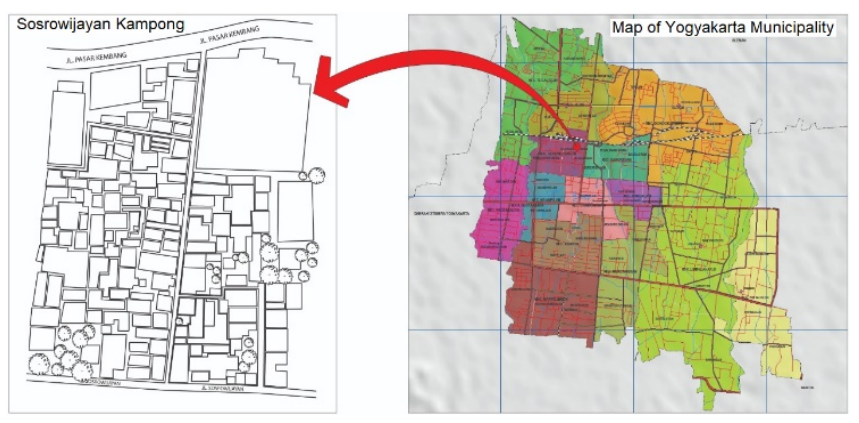

Fig. 2 Sosrowijayan Area

This Kampong has a privilege in attracting tourists, both domestic and foreign. Strategic location and inexpensive lodging are the main reasons for backpacker tourists to stay in this area [8][9]. Besides being a strategic location, Sosrowijayan Kampong also offers comfort and safety. This is also supported by the friendliness of the surrounding population and the ease of transportation and information [10]. The involvement of local residents in developing tourism is considered very important. According to Sajogyo [11], tourism development is inseparable from the participation of citizens to create the best service for tourists. Planning that is centered with involving the community, will help the community in recognizing the potential and existing problems. Thus began the creation of self-help in independence to overcome the problem.

\subsection{Housing and Enterprises in Sosrowijayan}

The development of the Malioboro area as the main tourist destination in Yogyakarta, has an impact on the growth of Sosrowijayan Kampong in accommodating tourist activities. The development of accommodation services is driven by a paradigm shift in the use of economic land such as the use of residential houses into lodging [12]. This certainly provides motivation for other residents to utilize housing as a business opportunity to improve the economy. This phenomenon is referred to as HBE or Home Based Enterprises, which is the use of housing as a micro business, run by family members or non-family members as employees [13]. The application of the HBE concept is adjusted to the function or type of business space, where it is necessary to make changes to the existing residential space layout which is adjusted by considering the benefits for the purpose of commercial activities [14]. In Kampong Sosrowijayan, the application of the HBE concept was influenced by the condition of the location of the Kampong located near the Malioboro area which was oriented towards tourism.

\subsection{Hybrid Culture in Sosrowijayan Kampong}

Cultural hybridity can occur in cultural practices in society such as language, customs, philosophy of life. Hybridity is formed through social relations and cultural intermarriage [15].

As a tourist Kampong, Kampung Sosrowijayan has many locals who open businesses related to tourist accommodation. The form of lodging here is quite unique because it blends with the Kampong residents. This has resulted in a fusion of culture, through native cultures of Indonesia that have developed before and foreign culture / culture of the western countries to make this place has its own charm [9]. Aside from lodging, the Sosrowijayan area is also filled with other supporting facilities such as travel agents, money changers, laundry and restaurants. The restaurant / cafe in Sosrowijayan serves a variety of foods ranging from Yogyakarta specialties to foreign food.

The purpose of this study is to analyses the home-based enterprises concerning on housing typology and hybrid spatial uses in the International Kampung of Sosrowijayan, Yogyakarta.

\subsection{Method}

The research site is in the Pasar Kembang Area, right in alley II Sosrowijayan Wetan, Sosromenduran Urban Kampong. The chosen location is located in RW 02: RT 11, RT 12, and RT 13. From 121 buildings in this area, eight residential with commercial activities were chosen as the research samples.

This research is focused on observations on residential homes in Kampung Sosrowijayan, DI Yogyakarta which is used as a business space as well as a residence. The method used in this research uses descriptive with visual analysis by examining the spatial function of HBE buildings in Sosrowijayan Kampong which includes zoning of space and activities that occur in it.

\subsection{State of The Art}

Previous research functioned as an analysis in enriching the discussion of research topics and used as a differentiator. In this study there were five journals related to the concept of HBE (Home-based Enterprised), including research conducted [16] HBE was compared as a component of the informal sector that is implemented in various places / cities. Then Marsoyo \& Astuti [13] discussed the prospects and strategies to maintain the existence of $\mathrm{HBE}$ in the viewpoint of entrepreneurs and the government. Meanwhile, Nisa \& Haryanto [12] discusses about the form of responses from local residents due to the rapid growth of tourism in the vicinity. The research model was also carried out by Puspita \& Rahmi [14], but discussed more about the form of transformation of residential houses into HBE due to the growth of educational facilities in the vicinity. While research conducted by Tyas [17] HBE is used as an alternative postearthquake development for the economic recovery of the community. Therefore, to complete the research on HBE, the author discusses the typology of HBE from Sosriwijayan 
dependence on government assistance, (10)

Kampong as an international kampong tourism and how hybrid culture is applied in the kampong as tourism accommodation.

\section{DISCUSSION}

In Sosrowijayan there are 121 buildings with diverse functions, the following percentage of building function data in Sosromenduran RW: 02. Based on these data, it is known that the majority of building functions in the Sosromenduran area are used as residential only at $56.20 \%$, while for the combination of residential and commercial (HBE) at 32.23\% and commercial functions at $11.5 \%$. Most building area in the International Kampong has an average of $23.5 \mathrm{~m} 2$.

TABLE I. NUMBER OF BUILDING FUNCTIONS IN THE KELURAHAN SOSROMENDURAN RW: 02

$\begin{array}{clr}\text { No } & \text { Functions } & \text { Total } \\ 1 & \text { Recidence } & 68 \\ 2 & \text { Recidence \& Travel } & 8 \\ 3 & \text { Recidence \& Small shop } & 8 \\ 4 & \text { Recidence \& Money changer } & 1 \\ 5 & \text { Recidence \& Shop } & 1 \\ 6 & \text { Recidence \& Lodging } & 5 \\ 7 & \text { Spa \& Massage } & 1 \\ 8 & \text { Recidence \& salon } & 1 \\ 9 & \text { Recidence \& Café } & 1 \\ 10 & \text { Small shop } & 7 \\ 11 & \text { Recidence \& photocopy center } & 2 \\ 12 & \text { Restaurant } & 2 \\ 13 & \text { Recidence \& Loan } & 3 \\ 14 & \text { Salon } & 2 \\ 15 & \text { Recidence \& Laundry } & 9 \\ 16 & \text { Tour Travel } & 2 \\ & \text { Total } & 121\end{array}$

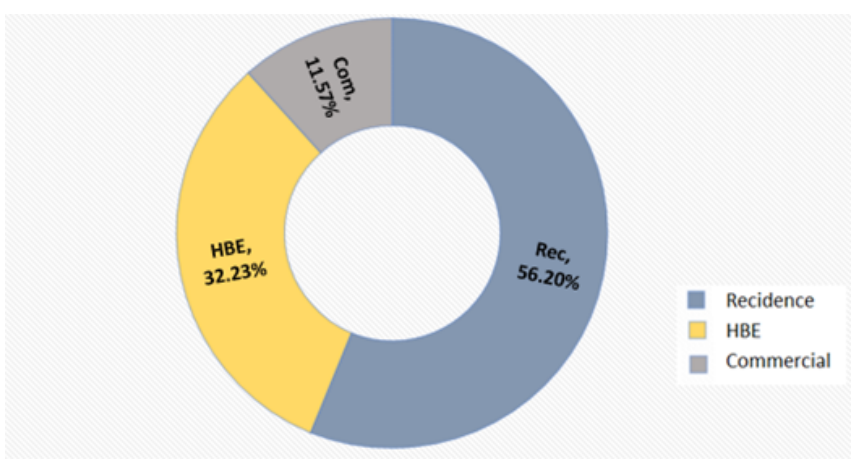

Fig. 3 Percentage of building functions in the Kelurahan Sosromenduran RW: 02

\section{A. Home-based Enterprises (HBE)}

Home-based Enterprises (HBE) can be defined as the use of housing as a micro-business, run by family members or non-family members as employees. There are three main components, namely, business, family, and home [13] [14]. The application of the HBE concept is adapted to the function or type of business space, as happened in Kampung Sosrowijayan, a tourism-oriented HBE house. Based on research conducted previously, According to Marsoyo \& Astuti [13], the influence of the existence of HBE in solving poverty is influenced by several internal and external factors, namely: (1) Business space conditions, (2) Income, (3) Age of entrepreneurs, (4) Age of HBE, (5) Lack of consumers, (6) Partnership, (7) competition, (8) location and profits, (9)
Technology. Program HBE also influenced by other factors, namely the experience, skills / knowledge related to home business can encourage access to markets [13][17]. Aside from being a reduction in the amount of poverty, HBE can also be utilized as a reduction in the unemployment rate. According to Tipple [16] HBE is an informal sector that can cope with increased demand for employment. Although the income generated at HBE houses has a low income, HBE can help household economic needs [18]

\section{B. HBE Typology in Sosrowijayan Kampong}

Building typology is the clarification of building types that are closely related to the building elements themselves, such as the type of building roof, the shape of the building plan, facade components attached to the building [19]. In short, typology is the study of several objects that have certain characteristics in common [20]. The characteristics of buildings the Sosrowijayan have character with an emphasis on the facade and floor plans, both of which can be developed in accordance with the wishes of the occupants [21][22]. In this study, focused on eight building samples with a discussion of how to divide the spatial zoning of HBE houses and the shape of the facade. Fig. 4 shows the location points of the HBE houses as the case study.

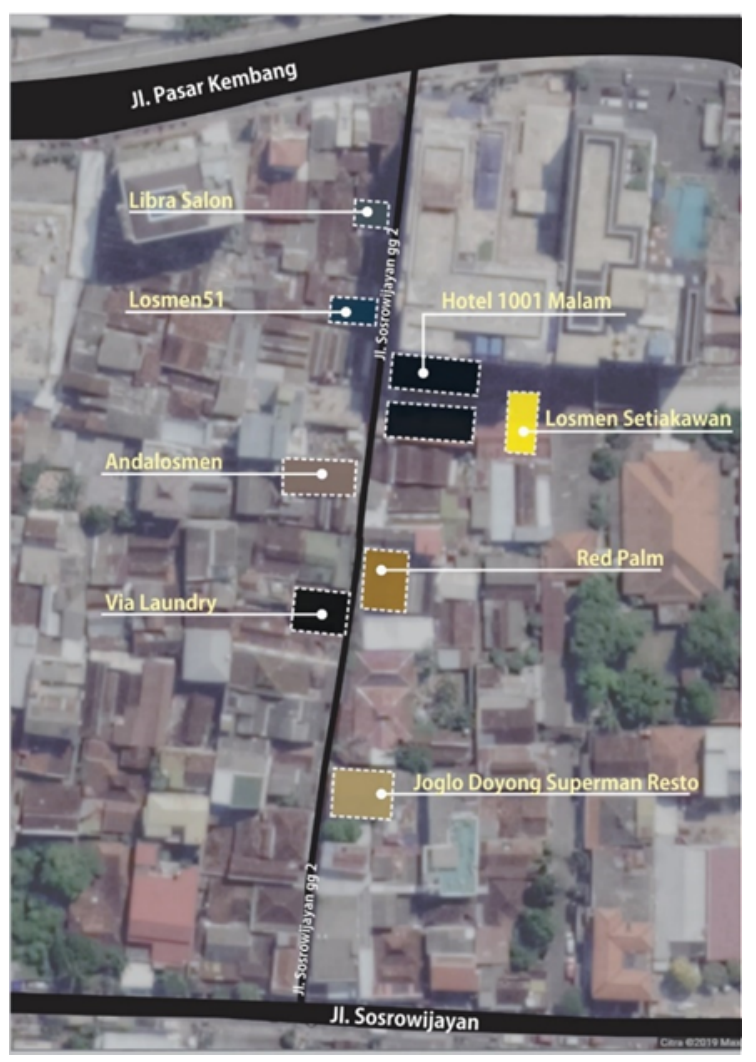

Fig. 4 Research Location Points

\section{Via Laundry}

Via Mr. Budi's Laundry is a HBE [13][14] house that was established in 2009. It has a 1-story building with a division of space, $14 \%$ of the area of the house is used for laundry business. Mr. Budi is a native of Kampung Sosrowijayan, based on the initial interview of a home-based business 


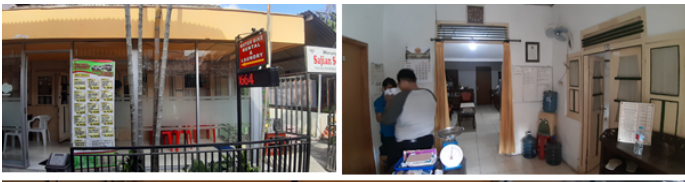

starting from a shop that sells basic needs of the surrounding community. However, with the phenomenon of change around the Kampong, the business turned into a laundry business. The large number of houses sold as hotels, shops, restaurants, etc., makes this Kampong adapt. For some residents who still live in this Kampong, see this phenomenon as a business opportunity. Moreover, as the Kampong became more known as a tourist Kampong, people began to change their homes into HBE houses.

According to Marsoyo in 2002 [14], Spatial change is one way of adaptation of the HBE house. Strategies in realizing HBE houses have 3 categories namely, (1) division of space, (2) expansion of space, and (3) change of space.
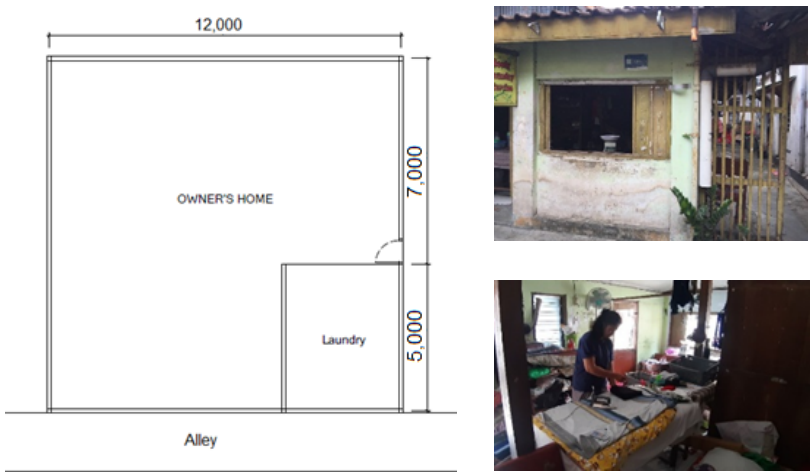

Fig. 5 Via Laundry

\section{Red Palm}

Red Palm is a motorbike, lodging, and internet cafe rental business owned by Mr. Adi Prabowo, this business was established in 2010. It has a one-story building with a 7-room inn capacity. The majority of customers at Red Palm are local tourists. Before 2010, this house was a family residence. Initially, the lodging business only had 2 rooms. But as they get older, family members one by one live separately. Thus, rooms for rent also increased.

In terms of spatial layout, the red palm building is largely used as a business. While the privacy space of the owner is only one room in the form of a $9 \mathrm{~m} 2$ bedroom. While other rooms are used as guesthouses, internet cafes, and shared rooms. Based on the percentage of business space is greater that is $83 \%$. Therefore, this composition of residential and business space shows that the Red Palm confirm as HBE [13][14].

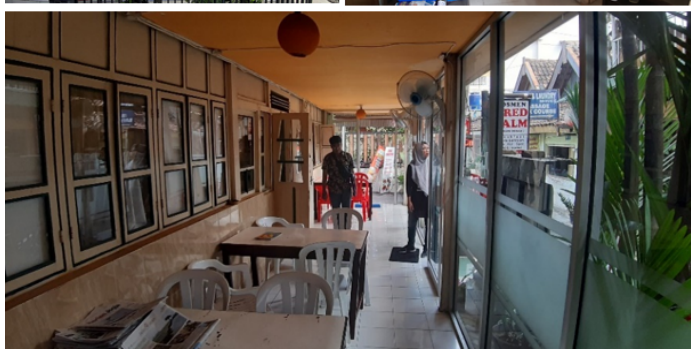

Fig. 6 Red Palm inn

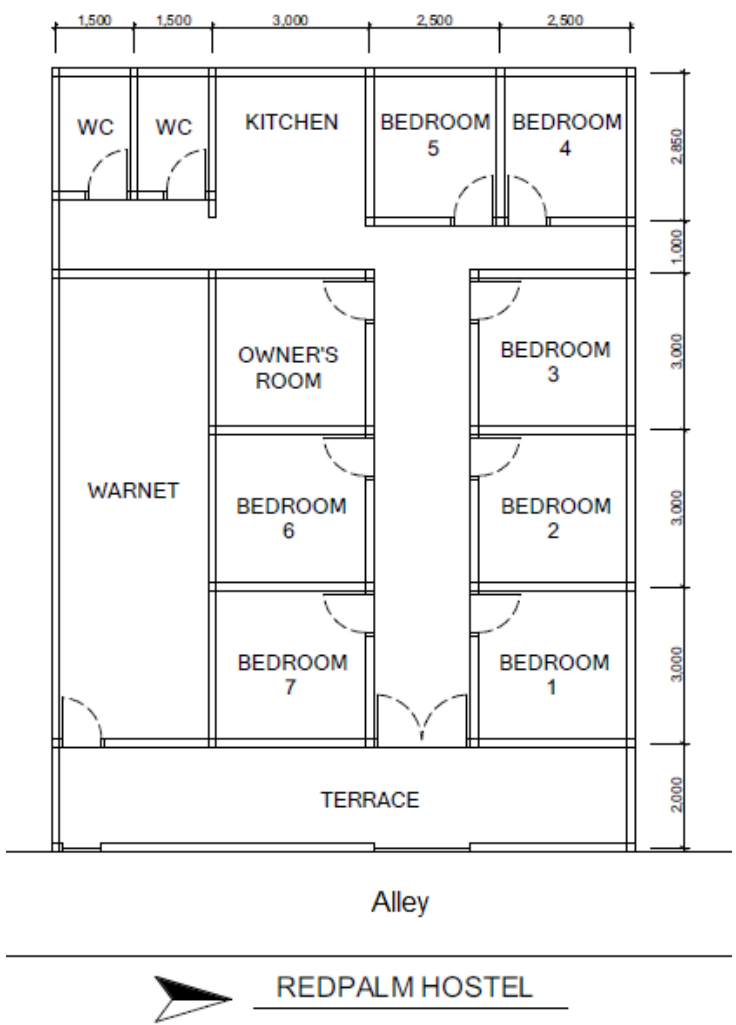

3. Inn 51

Inn 51 is an accommodation owned by Mr. Budiono, the beginning of this inn was founded in 1960. At the beginning of the inn, there were 5 rooms that were rented out to both foreign and local tourists. However, currently only 2 rooms are rented out, this is due to the increase in family members and tight competitiveness is one of the causes of decreased room rent. The profile of this activities shows that Inn 51 is HBE [13][14]. 

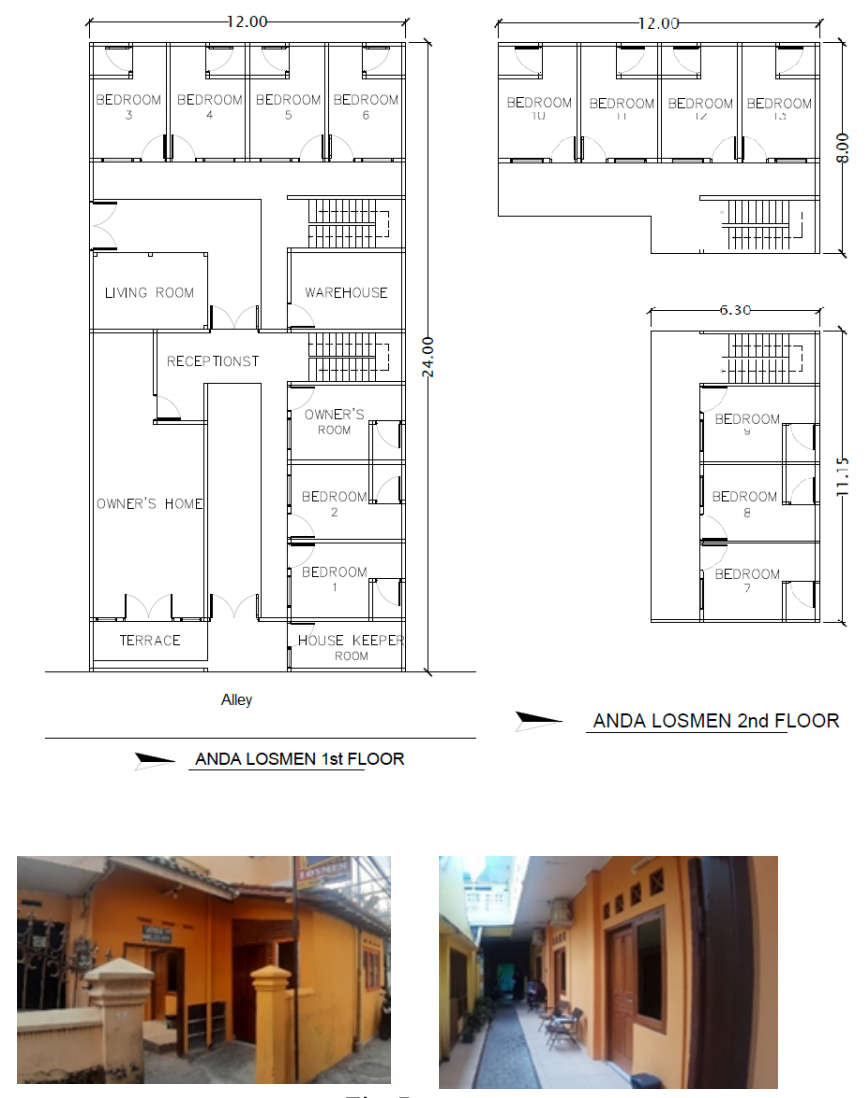

Fig. $7.51 \operatorname{lnn}$

\section{Anda Inn}

Anda Inn was founded around 1960, it is a place to stay and a guesthouse handed down from generation to generation of Mr. Yanto's family. This inn has 13 rooms. The average visitor at this inn is a local tourist.
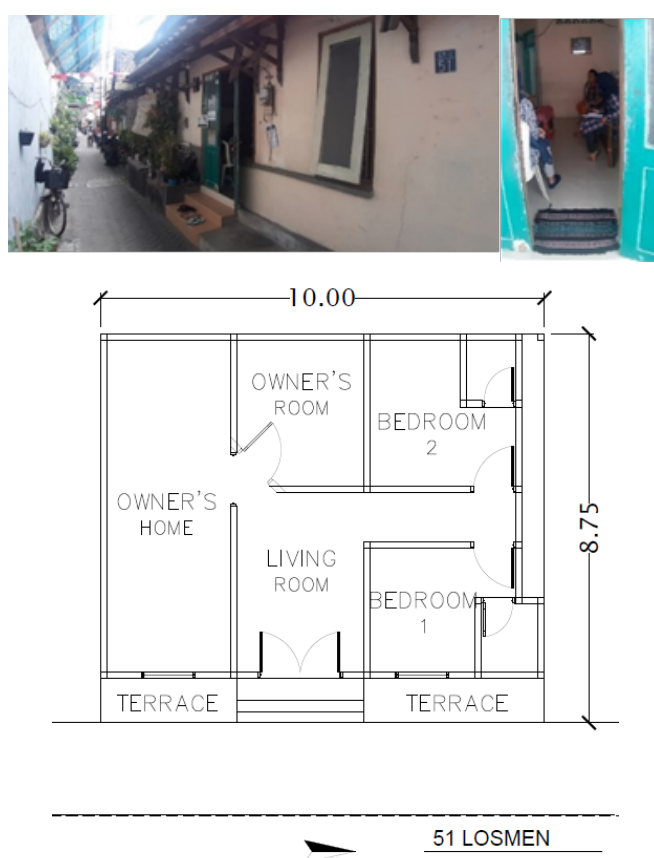

Fig. 8 Anda inn
Based on the zoning of the room, the inn has a two storey building with a total area of approximately $450 \mathrm{~m} 2$. In this hostel building, the proportion of residential houses with business space is greater business space. The number of family members who live here is 3 people, with a residence occupying the front area of the building. Therefore, the combination of residential and business activities are suitable for the HBE category [13][14].

\section{Setiakawan Inn}

Setiakawan Inn is a guesthouse located behind 1001 hotel. Access to this inn is quite easy with the signboard on the roadside. Although the location of the inn is not in the main alley, this inn has its own charm for visitors. According to the interview, the majority of visitors were foreign tourists. This is because this inn offers a location that provides a private atmosphere, away from noise, and friendly staff, making this inn a favorite choice for tourists. Based on the layout, this inn has 11 rooms with suite bathroom facilities. In this hostel, the proportion of residential space compared with business space is that the business space is greater than the residential space. This proportion is also confirmed that the Setiakawan Inn is a HBE [13][14].
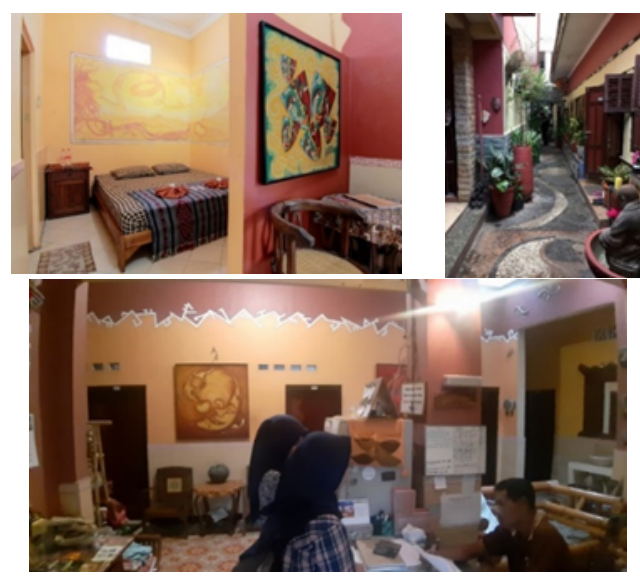

Fig. 9 Losmen Setia Kawan

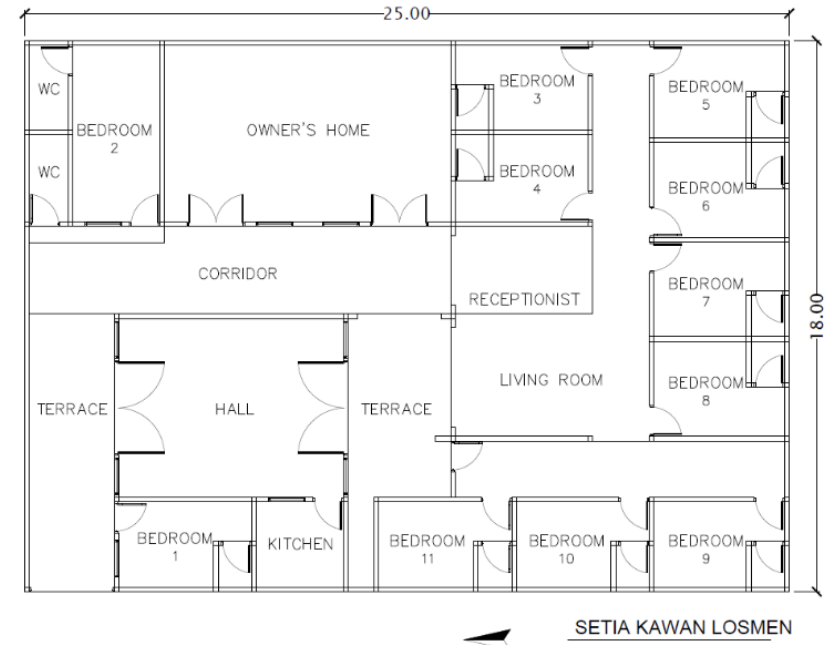

Fig. 10 Setia Kawan Floorplan 


\section{Libra Salon}

Libra salon, is one of the beauty salons in Sosrowijayan Kampong that has a dualism function, namely as a residence and also a salon. This building house has 2 floors with a total area of $56 \mathrm{~m} 2$ and is inhabited by 3 family members. This beauty salon business was founded in 2005 with the majority of visitors from foreign tourists. This shows that the Libra Salon is based on the HBE [13][14].
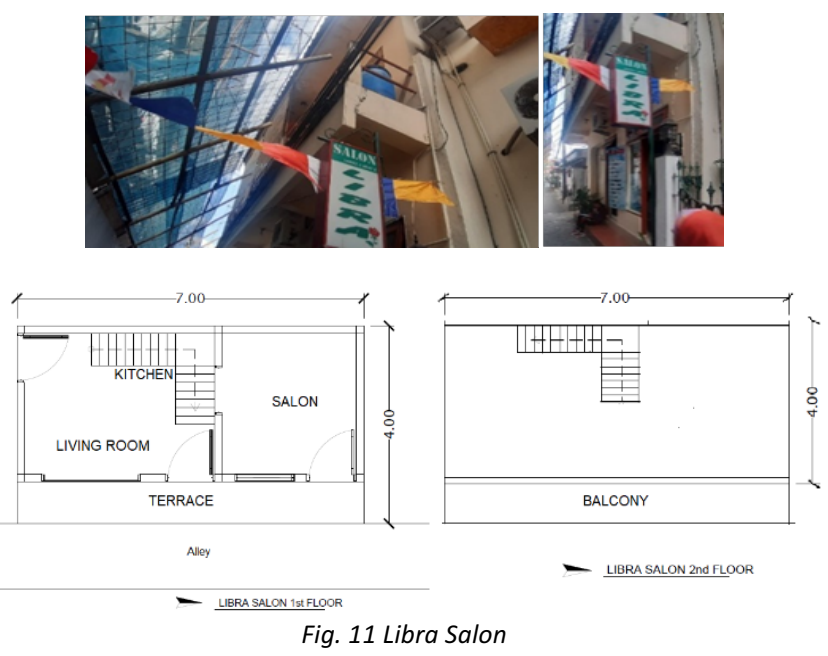

In this building, the salon area is approximately $9 \mathrm{~m}^{2}$ while the spa room is shared with the kitchen. When conditions are not used, this room can also function as a family room. While the 2 nd floor is used as a bedroom. The percentage of business space usage for a whole house is only around $16 \%$.

TABLE II. HBE AND NON HBE DATA IN SOSROWIJAYAN RW:02

\begin{tabular}{|c|c|c|c|c|c|c|}
\hline NO & $\begin{array}{l}\text { Bullding } \\
\text { Function }\end{array}$ & Manager & $\begin{array}{c}\text { Bullding } \\
\text { Type }\end{array}$ & $\begin{array}{l}\text { Year } \\
\text { of stay }\end{array}$ & $\begin{array}{c}\text { Business } \\
\text { establishment }\end{array}$ & Tourist \\
\hline \multicolumn{7}{|c|}{ HBE } \\
\hline 1 & Via Laundry & Bpk. Budi & 1 Floor & 1970 & 2009 & $\begin{array}{llr}2014-2016 & \text { more } & \text { foreign } \\
\text { tourists } \\
2016-2019 \\
\text { tourists }\end{array}$ \\
\hline 2 & Red Palm & $\begin{array}{l}\text { Bpik. Adi } \\
\text { Prabowo }\end{array}$ & 1 Floor & 1975 & 2010 & The majority of local tourists \\
\hline 3 & $\ln 51$ & Bpk. Budiono & 1 floor & 1960 & 1990 & local tourists \\
\hline 4 & Anda inn & Bpk. Yanto & 2 Floor & 1970 & \pm 1980 & $\begin{array}{l}\text { Foreign and local tourists } \\
\text { 2015-now many local }\end{array}$ \\
\hline 5 & Setia kawan Inn & Bpk Dalijo & 1 Floor & 1975 & \pm 1980 & $\begin{array}{l}\text { Foreign and local tourists } \\
2016 \text {-now many local }\end{array}$ \\
\hline 6 & Libra Salon & Bu Nining & 2 Floor & 1997 & 2005 & Foreign tourists \\
\hline & Non HBE & & & & & \\
\hline 7 & Joglo Doyong & Bpk. Marsoyo & 1 Floor & 1970 & 1980 & Foreign and local tourists \\
\hline 8 & $\begin{array}{l}\text { Hotel } \\
\text { Malam }\end{array}$ & $\begin{array}{l}\text { Bpk. } \\
\text { Mohammad }\end{array}$ & 2 Floor & - & 2010 & $\begin{array}{l}2010-2015 \text { more foreign } \\
\text { tourists } \\
2015-2019 \text { balanced }\end{array}$ \\
\hline
\end{tabular}

From all eight research samples, several similarities were found. The following is the data table of HBE and Non-HBE buildings located in Sosrowijayan Kampong:

Based on interviews, the average lodging business began in 1980 with visitors both foreign and domestic tourists. The season for foreign tourists takes place in July-August, 2019 while local tourists usually visit during the New Year, Eid or school holidays. According to the results of the survey, the longer the number of foreign tourists is decreasing. This is due to changes in the characteristics of Sosrowijayan as a tourist Kampong. The original inhabitants of this Kampong are decreasing, so that the Kampong activities that occur are also reduced. Though this urban kampong is a special attraction for foreign tourists.

TABLE III. PERCENTAGE OF BUSINESS SPACE IN SOSROWIJAYAN

\begin{tabular}{cccccc}
\hline No & Title & $\begin{array}{c}\text { Residential } \\
(\mathbf{m} 2)\end{array}$ & $\begin{array}{c}\text { Business } \\
(\mathbf{m} 2)\end{array}$ & $\begin{array}{c}\text { Total } \\
\text { area(m2) }\end{array}$ & $\begin{array}{c}\text { Percentage of } \\
\text { business space }\end{array}$ \\
\hline $\mathbf{1}$ & Via Laundry & 124 & 20 & 144 & $14 \%$ \\
\hline $\mathbf{2}$ & Red Palm & 17.55 & 145.8 & 163.35 & $89 \%$ \\
\hline $\mathbf{3}$ & Inn 51 & 55.5 & 32 & 87.5 & $37 \%$ \\
\hline $\mathbf{4}$ & Anda Inn & 44 & 410.25 & 454.25 & $90 \%$ \\
\hline $\mathbf{5}$ & Setia kawan Inn & 60 & 390 & 450 & $87 \%$ \\
\hline $\mathbf{6}$ & Libra Salon & 47 & 9 & 56 & $16 \%$ \\
\hline
\end{tabular}

Based on a survey of $6 \mathrm{HBE}$ houses in Sosrowijayan Kampong, it was found that the typology of HBE was the majority of business space $>80 \%$ for lodging businesses, while for other businesses it was $<40 \%$. In a guesthouse building, the average change in the number of rooms is influenced by the conditions of the family itself. The more family members that live, the less space for rent. Inns 51 is one inn to the reduction in the room, this is because these business owners already be elderly, so the family that originally lived outside the city settled in this house to accompany and care for the owner. In contrast to the Red Palm, this inn initially only rented 2 rooms but increased along with the reduction in family members who started working outside the city and had their own families. Thus, more space is leased.

\section{Hybrid Culture in Sosrowijayan Kampong}

Hybrid culture is a form of a long process of human history and culture, something that was not formed instantly but developed from the past to the present [23]. These developments can occur several factors, including the fastest development because it is formed through social relations and cultural cross-marriages [15]. The development of the tourism industry can also affect the culture of a place. The increasing number of foreign and local tourists will bring a new culture to the local community. In previous studies, the development of tourism has a big influence on the social changes of local residents. Starting from changes in livelihoods, use of foreign languages, the provision of supporting facilities tailored to the needs of tourists [24].

In the era of globalization, the development of information and communication technology spread rapidly. The entry of western values in Indonesia is a risk of the globalization era. Thus, in maintaining the local culture, the need for a strategy is right that local culture is not lost. Therefore, the need for strengthening cultural resistance local by way of taking the good side of foreign cultures which are then combined with the local culture [25], [26]. Cultural diversity inherent in the community can expand the role of culture in the development of tourism. This tourism not only provides increased income, but also makes it possible to promote a sustainable tourism model [27]. 
In this research, we will discuss how the cultural hybridity practices of Sosrowijayan Kampong, especially those that occurred at 1001 Malam Hotel and Joglo Superman Restaurant.

\section{Hotels 1001 Nights}

Hotel 1001 Malam is an accommodation in Sosrowijayan Kampong which has been operating since 2010. The current owner is not a native of Sosrowijayan Kampong, this hotel was bought and rebuilt in 2009 by Mr. Muhammad. The hotel building currently has 2 floors with a total of about 16 rooms, equipped with laundry facilities. The hotel visitors are foreign tourists and local tourists, with the majority of foreign tourists in the years 2010-2015, while in 2015-2019 visitors tend to be balanced both foreign and local. Based on interviews, tourists are distinguished by 2 seasons, namely the domestic tourist season and the foreign tourist season. The average domestic season is during school holidays, Eid and New Year. While foreign tourists visit during the June-August season.

This hotel does not have a restaurant. However, for hotel food supply in collaboration with Bedhot Resto (which is located opposite the hotel 1001 nights). The majority of visitors to this restaurant are foreign tourists so the food served is $90 \%$ western menu. This is because the average local tourist prefers to eat outside the hotel area. Usually the activity of tourists in this hotel is not much, just as a temporary resting place. So that during the day the hotel tends to be quiet. Moreover, this hotel business cannot be categorized as HBE because there is no owner staying in this hotel for living [13][14]. This business can be classify as a hybrid culture because this hotel is not only serving western but also this hotel lets the domestic visitors buy food out side and
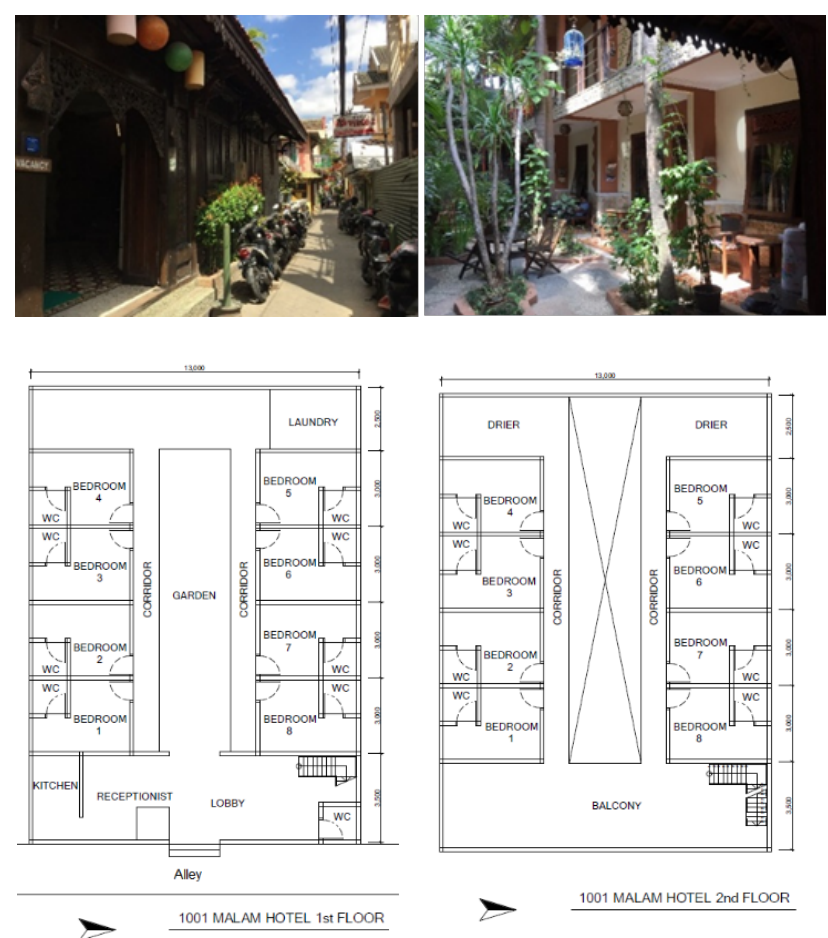

Fig. 121001 Malam Hotel
The following table is the difference characteristics of tourists in 1001 Night Hotels

TABLE IV. PERCENTAGE TABLE DATA OF HBE RESEARCH SAMPLES IN SOSROWIJAYAN KAMPONG

\begin{tabular}{lll}
\hline Room service & Foreign tourists & Domestic tourists \\
\hline Room Facilities & $\begin{array}{l}\text { Book a room by adjusting the } \\
\text { room capacity }\end{array}$ & $\begin{array}{l}\text { Book 1 room, (capacity of } 2 \\
\text { people) is used beyond the } \\
\text { capacity of people }\end{array}$ \\
\hline Travel & No need TV, prefer WIFI & TV and WIFI are required \\
\hline Food & $\begin{array}{l}\text { Tour \& Travel uses the services } \\
\text { of travel cooperation with } \\
\text { hotels }\end{array}$ & $\begin{array}{l}\text { Rarely use travel services from } \\
\text { hotels. Usually prefer the road } \\
\text { itself (using an online } \\
\text { motorcycle taxi / the like) }\end{array}$ \\
\hline order food through hotel room & prefer to eat outside the hotel \\
\hline service & \\
\hline
\end{tabular}

\section{Joglo Doyong Superman Restaurant}

Joglo Doyong Superman is a restaurant as well as an inn established since 1975. This building is conceptualized with a homey look that emphasizes the use of wooden dominance furniture, thus creating a warm and comfortable atmosphere. The average visitor of this restaurant is a foreign tourist, while for lodging receiving both foreign and domestic tourists. Lodging here totaling 7 rooms equipped with supporting facilities such as pantry, toilets, and parks that are used as communal outdoor spaces. This business is not categorized as HBE because the owner of this restaurant does not stay in this restaurant [13][14].

Based on observations and interviews, the development of hybrid culture in Joglo Doyong restaurant is seen in terms of space use activities. Basically, domestic tourists who stay here prefer to eat outside the restaurant area, they prefer to buy food around Malioboro. This was responded by Joglo Doyong by providing facilities in the form of a pantry so that tourists can cook food at this inn. In addition, for dining, domestic tourists are given the freedom to use outdoor space as a dining area, even though they do not order food through Joglo Doyong restaurant. This activities can be categorized as a hybrid culture [15]. 

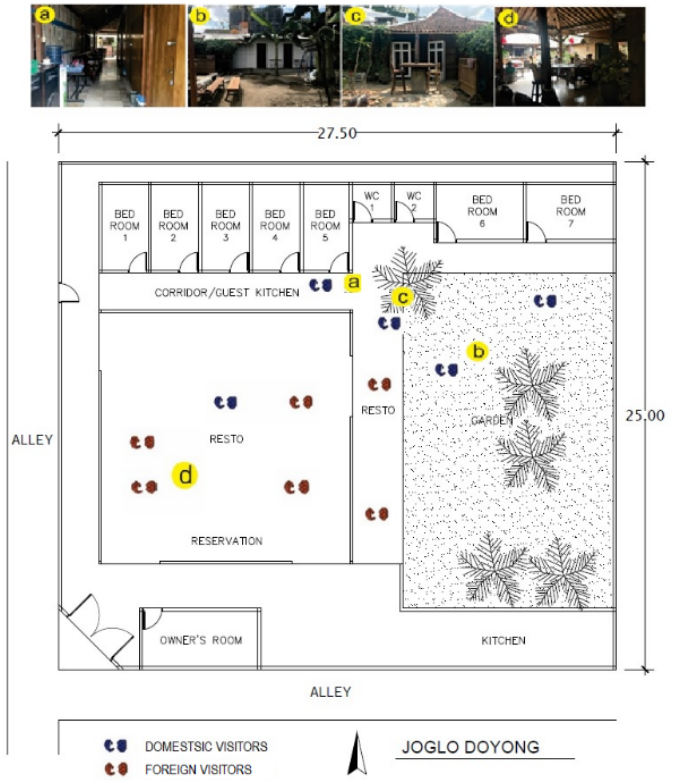

Fig. 13 Mapping of tourist activity at Joglo Doyong Superman.

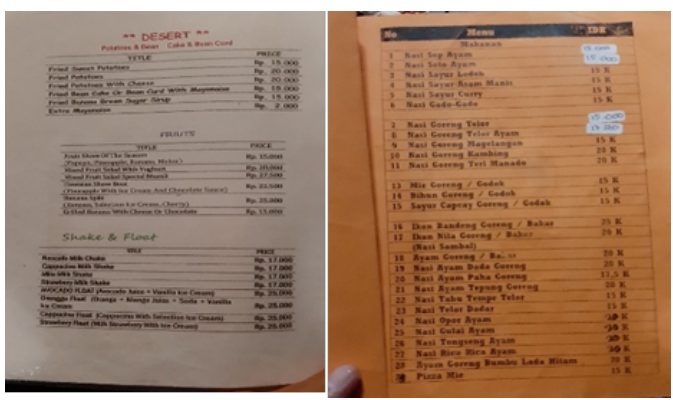

Fig. 14 Joglo Doyong Resto Menu

As for foreign tourists, prefer to stay and eat in the restaurant area. Most foreign tourist don't use pantry facility. However, this restaurant does not rule the possibility for domestic tourists to buy or not to buy food at this restaurant and the menu offered at this restaurant also varies, not only the western menu but also the typical Indonesian food menu (see Fig. 14).

\section{CONCLUSION}

From this research, it can be concluded that HBE supports the development of tourism activities in Sosrowijayan Kampong. HBE houses with businesses other than lodging, the average proportion of business space is smaller than the residences. The strategy of changing the function of space was chosen by the owner in responding to the limitations of land and space in accommodating the function of the residence and business space.

The HBE house in Sosrowijayan did not have a living room like a general typical home. Reception activities usually use for the business space as a place for social interaction. The design of the facade of the HBE house is also like a typical dwelling. But usually there is the addition of signage on the front of the building. While from the standpoint of hybrid culture, it can be concluded that the different cultural backgrounds of the tourists who come to bring hybrid culture that developed in the Kampong of Sosrowijayan. This difference has a big influence on the social change of local residents. As is the case with changes in people's livelihoods, the language used, to the food sold to suit the tastes of tourists or visitors to the Kampong.

Finally, the impact of hybrid culture will significantly contribute to the social and economic incomes for the local businesses. This this hybrid culture could be the tourism identity of the International Kampong of Sosrowijayan. The future challenges will be faced by community is that how to protect and manage the hybrid culture as a distinctive attraction to support the tourism development in the special city of Yogyakarta.

\section{ACKNOWLEDGMENTS}

This paper is the result of the activities financed by the Ministry of Research and Technology of Higher Education through the National Strategy scheme in 2017-2019. The author says greatly love for Research and Technology Ministry of Higher Education that has funded the research of National Strategy for three years. A nice appreciation is to deliver to Astrie Ken Rahajeng, the student supporting the survey in the Sosrowijayan Kampong. Thanks also go to the DPPM UII and the FTSP UII who have supported the researcher with the awesome management.

\section{REFERENCES}

[1] Dinas Pariwisata Daerah Istimewa Yogyakarta. (2018). Statistik Kepariwisataan. Yogyakarta: Dinas Pariwisata Daerah Istimewa Yogyakarta.

[2] G. Lufityanti. (2018). Kunjungan Travel DIY Tahun 2017. [online] tribunjogja.com. Available at: https://jogja.tribunnews.com/2018/02/02/kunjungan-travel-diy-tahun2017-increasing-significant [Accessed 13 Jul. 2019].

[3] T. M. G. Syaifudin. (2017). Banyak Destinasi Baru, Jumlah Wisatawan di Yogyakarta Diprediksi Meningkat. [online] KOMPAS.com. Available at:https://travel.kompas.com/read/2017/06/24/100300427/banyak.dest inasi.baru.jotal.wisatawan.di.yogyakarta.dip predicted.increasing [Accessed 3 Jul. 2019].

[4] F. S. Evani. (2018). Yogyakarta Ditetapkan Sebagai Kota Kebudayaan ASEAN. [online] beritasatu.com. Available at: https://www.beritasatu.com/nasional/518466/yogyakarta-ditetapkansebagai-kota-kebudayaan-asean [Accessed 3 Jul. 2019].

[5] W. D. Suparjo. (2018). DIY Diusulkan Sebagai Kota Kebudayaan $A S E A N$. [online] Rri.co.id. Available at:

http://rri.co.id/yogyakarta/post/berita/533306/seni_budaya/diy_diusul kan_seb__ebeb__cebultur_asean.html [Accessed 3 Jul. 2019].

[6] D. Widiyanto. (2018). Yogyakarta Kota Budaya ASEAN. [online] krjogja.com. Available at:

https://www.krjogja.com/web/news/read/81257/Yogyakarta_Kota_Bu daya_ASEAN [Accessed 3 Jul. 2019].

[7] H. Bernas. (2018). Ini 6 Hal Unik Tentang Jogja yang Membuat Selalu ingin Kembali (Bagian Kedua-Habis) - bernas.id. [online] Bernas.id. Available at: https://www.bernas.id/61041-ini-6-hal-uniktentang-jogja-yang-membuat-always-ingin- $\mathrm{k} \% 20$ returning-partseconded-\%20after\%20.html [Accessed 3 Jul. 2019].

[8] I. K. C. Putri. (2015). Sekilas Tentang Kampung Internasional Sosrowijayan. [online] KOMPASIANA. Available at: https://www.kompasiana.com/intanmino/550d57058133115d22b1e30 9/sekilas-about-kampung-internasional-sosrowijayan [Accessed 20 Dec. 2019].

[9] A. B. Santoso. (2015). Sosrowijayan, Kampung Kecil di Yogyakarta yang Disukai 'Turis-turis Backpacker' - Tribunnews.com. [online] 
[27] A. Artal-Tur, M. Villena-Navarro, and L. Alamá-Sabater, The relationship between cultural tourist behavior and destination sustainability. Anatolia Vol. 29, pp. 237-251. 2018.
Tribunnews.com. Available at:
http://www.tribunnews.com/travel/2015/01/22/sosrowijayankampung-kecil-di-yogyakarta-yang-disukai-turis-turis-backpacker [Accessed 1 Jul. 2019].

[10] R. A. Permatasari, and H. Wahyono, The Attraction of Sosrowijayan Area, Yogyakarta As A Tourist Kampong For Foreign Tourists. Journal of Urban Development Vol 5, pp. 9-16, 2017.

[11] S. M. Utami, Journal of Local Community Involvement in Developing Tourism Potential in Semarang Regency. Social Sciences Forum Vol. 40 , pp. 84-96, 2013.

[12] A. F. Nisa, and R. Haryanto, Study on the existence of Malioboro shopping tourism on the growth of accommodation services on Jalan Sosrowijayan and Jalan Dagen. Journal of PWK Engineering Vol 1 (3), pp. 946, 2014.

[13] A. Marsoyo, and W. K. Astuti, The Prospect of Poor Home-Based Enterprises in Yogyakarta. 2nd ICIAP "Space for the Next Generation", 1-8, 2014.

[14] L. R. Puspita, and D. H. Rahmi, Horizontal spatial transformation at home based enterprises in Kampung Karangasem, Depok, Sleman. Journal of Architectural Research and Design Studies, pp. 1-9. 2019.

[15] M. A. Humaedi, Hybrid Culture of Cirebon Community. Humanities Volume 25, pp. 281-295. 2013.

[16] G. Tipple, The Place of Home-based Enterprises in the Informal Sector: Evidence from Cochabamba, New Delhi, Surabaya and Pretoria. Urban Studies, pg. 1-42. April, 2005.

[17] W. P. Tyas, Home-based enterprises approach for post disaster housing: learn from post disaster redevelopment program in developing countries. International Conference, Intelligent Planning Towards Smart Cities, CITIES 2015 , pp. 139-145. 2015.

[18] K. V. Gough, A. G. Tipple, and M. Napier, Making a Living in African Cities: The Role of Home-based Enterprises in Accra and Pretoria. International Planning Studies, Vol. 8, No. 4, pp. 254-277. 2003.

[19] Y. Firzal, Old Building Typology. Local Wisdom-Online Scientific Journal Vol: III, No.2, pp. 33-42. 2011.

[20] T. Santri, Typology of Kampong Tourism Houses in Ngluwuk Hamlet Batik Kampong Gedhog Tuban. RUAS Journal Volume 15 No 2, pp. 32-39. 2017.

[21] E. Wahyunigtyas, (2001). Threshold and Conception of Tourist Kampong Model in Sosrowijayan Wetan, Yogyakarta City. [Online] eprints.undip.ac.id. Available at: http://eprints.undip.ac.id/10979/1/2001MTA985.pdf

[22] A. R. Dani, and D. Wijono, Typomorphology of the Facade of Shopping Buildings along the Segment. IPLBI Scientific Meeting, pg. 64-68. 2017.

[23] I. Setiawan, (2016, December 11). Cultural Hybridity in Perspective Pathways . [Online] Matatimoer Institute. Available at: http://matatimoer.or.id/wp-content/uploads/2016/12/Hibriditasbudaya-dalam-alur-perspektif.pdf

[24] M. Furqan, and M. Khairulyadi, Impact of foreign tourists on socialcultural change of community culture. JIM Fisip Unsiah, pp. 1-17. 2017.

[25] A. S. Mubah, Strategies to Increase Local Cultural Resilience in Facing. Journal of Airlangga Vol. 24 No. 4, pp. 302-308. 2011.

[26] S. Farina, (2018, November 26). The Existence of Local Culture in Facing Cultural Globalization. [Online] Kompasiana.com. Available at: https:/www.kompasiana.com/sitifarina8501/5bfae7be677ffb79b12f3 668/existence-cultural-local-dalam-cope-globalisationculture?page $=1$ 